\title{
SATB1 is an independent prognostic marker for gastric cancer in a Chinese population
}

\author{
XIAOMING LU ${ }^{1 *}$, CHAO CHENG ${ }^{1 *}$, SHIKAI ZHU ${ }^{2}$, YUN YANG ${ }^{3}$, LIDUAN ZHENG ${ }^{4}$, \\ GUOBIN WANG ${ }^{1}$, XIAOGANG SHU ${ }^{1}, \mathrm{KE} \mathrm{WU}^{1}, \mathrm{KE} \mathrm{LIU}^{1}$ and QIANG TONG ${ }^{1}$ \\ Departments of ${ }^{1}$ Gastrointestinal Surgery, ${ }^{2}$ Pancreatic Surgery, ${ }^{3}$ Obstetrics and Gynecology, and \\ ${ }^{4}$ Pathology, Union Hospital, Tongji Medical College, Huazhong University of Science and Technology, \\ 1277 Jiefang Avenue, Wuhan, Hubei 430022, P.R. China
}

Received May 9, 2010; Accepted June 23, 2010

DOI: $10.3892 /$ or_00000945

\begin{abstract}
Special AT-rich sequence binding protein 1 (SATB1), a new type of gene regulator, has been reported to express in various human cancers and may associate with the malignant potential. However, there are few data available on SATB1 expression and its relationship to tumor progression in gastric cancer. The current study was designed to examine the SATB1 expression in gastric cancer and to correlate it with clinical outcome. SATB1 expression was studied by qRT-PCR, Western blotting and immunohistochemistry, respectively. The correlations between SATB1 expression and clinicopathological factors were statistically analyzed. SATB1 mRNA expression was significantly up-regulated in gastric cancer specimens as compared with that in normal tissues $(\mathrm{P}<0.001)$. Overexpression of SATB1 protein was observed in gastric cancer cell lines by Western blotting. Fifty-three (44.9\%) cases showed positive staining for the SATB1 proteins by immunohistochemistry. The expression of SATB1 mRNA agreed well with the Western blotting and immunohistochemical findings $(\mathrm{P}<0.001)$. SATB1 expression was positively correlated with age, depth of invasion, lymph node metastasis, distant metastasis and TNM stage. Moreover, Kaplan-Meier analysis revealed that SATB1 overexpression was associated with a significantly worse survival $(\mathrm{P}<0.001)$. Further multivariable analysis indicated that SATB1 expression was an independent prognostic indicator for gastric cancer $(\mathrm{P}=0.023)$. In summary, overexpression of SATB1 correlated with metastatic potential of human gastric cancer and would be
\end{abstract}

Correspondence to: Dr Qiang Tong, Department of Gastrointestinal Surgery, Union Hospital, Tongji Medical College, Huazhong University of Science and Technology, 1277 Jiefang Avenue, Wuhan, Hubei 430022, P.R. China

E-mail: etongqiang@yahoo.com.cn

*Contributed equally

Key words: SATB1, gastric cancer, prognosis, metastasis a novel independent prognostic marker for predicting the outcome of gastric cancer.

\section{Introduction}

Gastric cancer is one of the most prevalent malignancies and the second leading cause of cancer-related death worldwide $(1,2)$. Although considerable improvements have been made in diagnostic techniques, surgical treatment, chemotherapy, and radiotherapy in last decades, patients with advanced gastric cancer still face poor prognosis $(3,4)$. It has been reported that, in China, gastric cancer remains the most frequently diagnosed cancer with a high case fatality, and the overall 5-year survival rate of patients with diagnosed gastric cancer ranges from 20 to $30 \%(5,6)$. Gastric carcinogenesis is a complex and incompletely understood process that is determined by environmental and genetic factors. Therefore, identification of molecular markers to predict the potential of tumor progression and prognosis of patients is extremely desirable for designing appropriate clinical individualization therapy.

Special AT-rich binding protein 1 (SATB1), which is 763 amino acids in length and locates at human chromosome 3 p23, is a cell type-specific nuclear matrix attachment region (MAR) DNA-binding protein and has the ability to participate in the chromatin higher structure package and tissuespecific gene expression (7-9). It provides docking sites for specialized DNA sequences and enzymes to regulate gene expression over long distances. Therefore, it has been considered to be a new type of gene regulator (9-11). In 1992, Dickinson et al reported that SATB1 was predominantly expressed in thymocytes, which was critical for proliferation, differentiation and apoptosis of T-cells $(8,12)$. Recently, a growing body of evidence showed that SATB1 was also highly expressed in various malignant tumors, such as breast cancer, lung cancer and laryngeal cancer, which might play a crucial role in facilitating tumor invasion and metastasis. Moreover, SATB1 expression is also significantly associated with poor prognostic parameters in a variety of cancers (13-16).

However, SATB1 expression and its clinical significance in gastric cancer remain still unclear. In this study, we 
investigated characterization of SATB1 expression in gastric cancer and determined its clinicopathological and prognostic significance.

\section{Materials and methods}

Clinical sample collection. One-hundred and eighteen tissue samples of the primary gastric cancers were collected from patients who had undergone surgical resection at Department of Gastrointestinal Surgery of Union Hospital (Wuhan, China) from 2002 to 2005. This period was selected to provide a sufficient period of follow-up to determine patient prognosis. The corresponding non-tumor tissues served as controls, which were at least $5 \mathrm{~cm}$ away from the margin of the tumor and were confirmed as such by two experienced clinical pathologists. All the patients were closely followed regularly every month after surgery. None of them received preoperative chemotherapy or radiotherapy. Clinical data were obtained from well-documented medical records, and the TNM staging was assessed according to the criteria proposed by the International Union against Cancer (17). All patients gave written informed consent, and the study protocol and patient information sheet were approved by the Ethics Committee of Union Hospital, Tongji Medical College, HUST (China). Specimens were anonymized and analyzed in a double blinded manner. Freshly tissue samples were obtained from all of the resected specimens and were rapidly frozen at $-80^{\circ} \mathrm{C}$ for storage until analysis. In addition, the remainder of each specimen was fixed in $10 \%$ phosphatebuffered formalin and paraffin-embedded for histological analysis.

Cell culture. Human gastric epithelial cell line GES-1 and gastric cancer cell lines BGC-823 and MKN-28 were maintained in Dulbecco's modified Eagle's medium (DMEM) supplemented with $10 \%$ fetal bovine serum, $100 \mu \mathrm{g} / \mathrm{ml}$ penicillin and $100 \mu \mathrm{g} / \mathrm{ml}$ streptomycin and cultured at $37^{\circ} \mathrm{C}$ in a $5 \% \mathrm{CO}_{2}$ incubator. After incubation for the desired periods, cell lines were harvested for subsequent experiments.

Western blotting. Western blotting was used to confirm the expression of SATB1 in GES-1, BGC-823 and MKN-28. Total protein was extracted using PROPREP solution (BestBio Inc., Shanghai, China). Each $40 \mu \mathrm{g}$ aliquot of total protein was loaded on a $10 \%$ SDS-PAGE gel $(25 \mu \mathrm{g})$ at $100 \mathrm{~V}$ for $1 \mathrm{~h}$. After electrophoresis, the proteins were transferred onto PVDF membranes (Millipore, Billerica, $\mathrm{MA}$ ), and then blocked in 5\% skim-milk for $60 \mathrm{~min}$ at room temperature. Following, the SATB1 protein was incubated with rabbit polyclonal antibody at a 1:500 dilution overnight at $4^{\circ} \mathrm{C}$. Next, the membranes were incubated with horseradish peroxidase-conjugated secondary antibody. Expression of SATB1 protein was normalized to $B$-actin expression (Boster Ltd., Wuhan, China). Then proteins were visualized by ECL Western blotting substrate (Pierce, Rockford, IL) according to the manufacturer's instructions.

Quantitative real-time $R T-P C R$. Total RNA was obtained from frozen tissue samples and cell lines using an RNeasy
Mini Kit (Qiagen GmbH, Hilden, Germany) according to the manufacturer's instructions. Quantitative real-time RT-PCR was subjected to cDNA which was synthesised from $1.0 \mu \mathrm{g}$ of total RNA. SATB1-specific primers were designed as follows: (forward) 5'-GTGGGTACGCGATGAACTGA-3' and (reverse) 5'-TGTTAAAAGCCAGTGCAA-3'. The glyceraldehydes-3-phosphate dehydrogenase (GAPDH) gene was used as an internal control. The forward primer for GAPDH was 5'-TTGGTATCGTGGAAGGACTCA-3' and the reverse primer was 5'-TGTCATCATATTTGGCA GGTT-3'. All real-time PCR reactions were performed in a Applied Biosystems StepOnePlus ${ }^{\mathrm{TM}}$ Real-Time PCR System (Applied Biosystems Inc., Foster City, CA) using the SYBR ${ }^{\circledR}$ Green Real-time PCR Master Mix (Applied Biosystems Inc.). Briefly, a master mixture, consisting of $10 \mu \mathrm{l} \mathrm{SYBR-}$ Green real-time PCR Master Mix, $1 \mu 1$ SATB1-specific primers, and $1 \mu \mathrm{l}$ cDNA from each clinical sample was prepared on ice. The final volume was adjusted to $20 \mu \mathrm{l}$ with distilled water, and the aliquots were immediately applied to the glass capillary tubes. Then, the reaction was carried out under the following conditions: initial denaturation at $95^{\circ} \mathrm{C}$ for $10 \mathrm{~min}$, followed by 40 cycles of denaturation at $95^{\circ} \mathrm{C}$ for $15 \mathrm{sec}$, annealing at $60^{\circ} \mathrm{C}$ for $60 \mathrm{sec}$, and extension at $72^{\circ} \mathrm{C}$ for $30 \mathrm{sec}$. The cycle threshold $(\mathrm{Ct})$ is the fractional cycle number at which the fluorescence exceeds a fixed level above baseline. The amount of SATB1 mRNA in tumor or non-tumor tissues, standardized against the amount of GAPDH mRNA $(18,19)$, was expressed as $\Delta \mathrm{Ct}_{\text {tumor }}$ or $\Delta \mathrm{Ct}_{\text {non- }}$ tumor $=\mathrm{Ct}_{\mathrm{SATB} 1}-\mathrm{Ct}_{\mathrm{GAPDH}}$. The experiment was performed in duplicate, and the mean value of $\Delta \mathrm{Ct}_{\text {tumor }}$ or $\Delta \mathrm{Ct}_{\text {non-tumor }}$ was used to calculate the ratio of the amount of SATB1 mRNA in tumor tissue to that in non-tumor tissue. The ratio of the amount of SATB1 mRNA in tumor tissue to that in non-

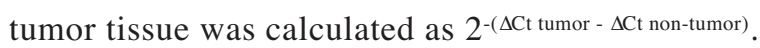

Immunohistochemistry. The expression of SATB1 protein was investigated by immunostaining using SABC kits (Boster Ltd.) according to the manufacturer's protocol. Sections (4 $\mu \mathrm{m}$ thick) of formalin-fixed and paraffin-embedded tumor tissue specimens were prepared for immunohistochemical analysis. Briefly, after deparaffinisation and blocking endogenous peroxidase activity, antigen retrieval was performed by microwaving the sections. A commercial rabbit polyclonal antibody for human SATB1 (Abcam Inc., Cambridge, CA) was applied as primary antibody at a 1:200 dilution, and antigen-antibody reaction was incubated overnight at $4^{\circ} \mathrm{C}$. After washing with $1 \mathrm{X}$ PBS $(0.01 \mathrm{M}, \mathrm{pH} 7.4)$, the slides were incubated with biotinylated secondary antibody and Streptavidin-Biotin Complex reagent, both for $30 \mathrm{~min}$ at $37^{\circ} \mathrm{C}$. Each incubation step was followed by washing 3 times with $1 \mathrm{X}$ PBS. After incubation with diaminobenzidine for 5-8 min, the sections were counterstained with hematoxylin. Following dehydration in ethanol and xylene, the slides were visualized for microscopic interpretation. As negative controls, samples were incubated with PBS instead of the primary antibody.

Staining analysis. The reactivity degree of SATB1 in each immunostained slide was assessed independently by two pathologists unaware of the clinicopathological details. 
Table I. Relationships between SATB1 mRNA expression and clinicopathological characteristics.

\begin{tabular}{|c|c|c|c|c|}
\hline \multirow[b]{2}{*}{ Characteristics } & \multicolumn{3}{|c|}{ SATB1 mRNA expressior } & \multirow[b]{2}{*}{ P-value } \\
\hline & $\mathrm{n}$ & $\begin{array}{c}\text { High } \\
(n=56)\end{array}$ & $\begin{array}{c}\text { Low } \\
(n=62)\end{array}$ & \\
\hline Age (years) & & & & 0.011 \\
\hline$\geq 65$ & 55 & 33 & 22 & \\
\hline$<65$ & 63 & 23 & 40 & \\
\hline Gender & & & & 0.432 \\
\hline Male & 78 & 35 & 43 & \\
\hline Female & 40 & 21 & 19 & \\
\hline Tumor size $(\mathrm{cm})$ & & & & 0.213 \\
\hline$\geq 5$ & 71 & 37 & 34 & \\
\hline$<5$ & 47 & 19 & 28 & \\
\hline \multicolumn{5}{|l|}{ Tumor location } \\
\hline Upper & 12 & 7 & 5 & $0.231^{\mathrm{a}}$ \\
\hline Middle & 43 & 24 & 19 & $0.102^{\mathrm{b}}$ \\
\hline Lower & 63 & 25 & 38 & $0.070^{\mathrm{c}}$ \\
\hline Depth of invasion & & & & 0.021 \\
\hline $\mathrm{T} 1+\mathrm{T} 2$ & 51 & 18 & 33 & \\
\hline $\mathrm{T} 3+\mathrm{T} 4$ & 67 & 38 & 29 & \\
\hline TNM stage & & & & 0.037 \\
\hline $\mathrm{I}+\mathrm{II}$ & 54 & 20 & 34 & \\
\hline III + IV & 64 & 36 & 28 & \\
\hline Lymph node metastasis & & & & 0.013 \\
\hline Present & 66 & 38 & 28 & \\
\hline Absent & 52 & 18 & 34 & \\
\hline Distant metastasis & & & & 0.018 \\
\hline Present & 16 & 12 & 4 & \\
\hline Absent & 102 & 44 & 58 & \\
\hline
\end{tabular}

${ }^{\mathrm{a} U p p e r}$ vs. lower; ${ }^{\mathrm{b}}$ middle vs. lower; ${ }^{\mathrm{c}}$ upper and middle vs. lower.

According to the percentage of positive tumor cells, the staining was scored semi-quantitatively as follows: $0,<5 \%$ cells stained; $1,6-25 \%$ cells stained; $2,26-50 \%$ cells stained; $3,>50 \%$ cells stained. Slices with scores $0-1$ were regarded as having a 'low expression', whereas slices with scores 2-3 were defined as having a 'high expression'. The allocation of tumors and scoring staining by the two pathologists was similar. In the cases of disagreement, slides were reevaluated and discussed until consensus was achieved.

Statistical analysis. All Statistical analysis was carried out using SPSS 16.0 statistical software package (SPSS Inc., Chicago, IL). For statistical analysis, the patients were classified into high and low SATB1 mRNA expression groups, based on whether they were above or below the mean value (high SATB1 expression group, $\mathrm{n}=56$; low SATB1 expression group, $n=62$ ). The difference between SATB1 mRNA
$\mathbf{A}$

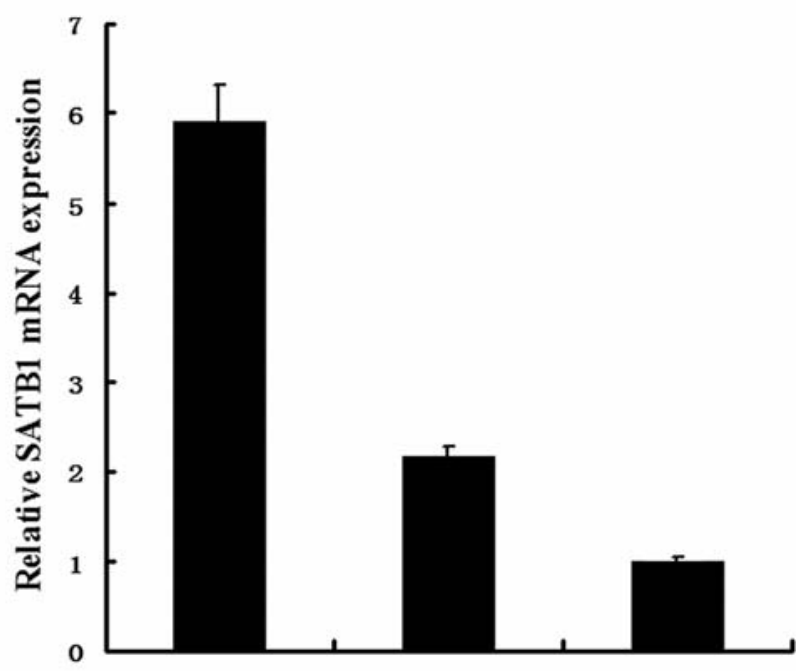

B

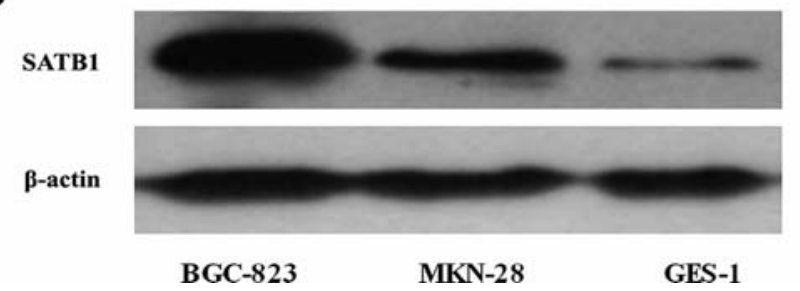

Figure 1. SATB1 expression in three kinds of cell lines by quantitative real-time RT-PCR assay (A) and Western blot analysis (B). To normalize SATB1 expression, GAPDH or B-actin was used as an internal control. SATB1 protein expression paralleled with SATB1 mRNA expression. Error bars showed the SD of the mean.

expression in tumor tissue and that in corresponding nontumor tissue was evaluated using Student's t-test. The twotailed $\chi^{2}$ test or Fisher's exact test was used to analyze the associations between SATB1 expression and clinicopathological features of gastric cancer. The correlation between SATB1 mRNA and protein expression was determined by Pearson's coefficient correlation analysis. Survival curves were plotted by the Kaplan-Meier method and the difference between survival curves was analyzed by the log-rank test. Survival data were evaluated using univariate and multivariate Cox regression analysis. In all of the tests, $\mathrm{P}<0.05$ was considered to be statistically significant.

\section{Results}

Patients. In this study, there were 78 men and 40 women with a mean age of 60.3 years (range, 27-81 years). The median follow-up period of the patients was 34.5 months with a range from 5 to 91 months. All deaths were attributable to gastric cancer. We examined tissue specimens from all the 118 primary tumors. Patient characteristics are detailed in Table I.

Expression of SATB1 in gastric cancer cell lines. The levels of SATB1 mRNA expression in BGC-823 and MKN-28 were 5.9-fold and 2.2-fold higher than that in GES-1, respectively. Moreover, concordant expression was observed between SATB1 mRNA and protein expression (Fig. 1). 

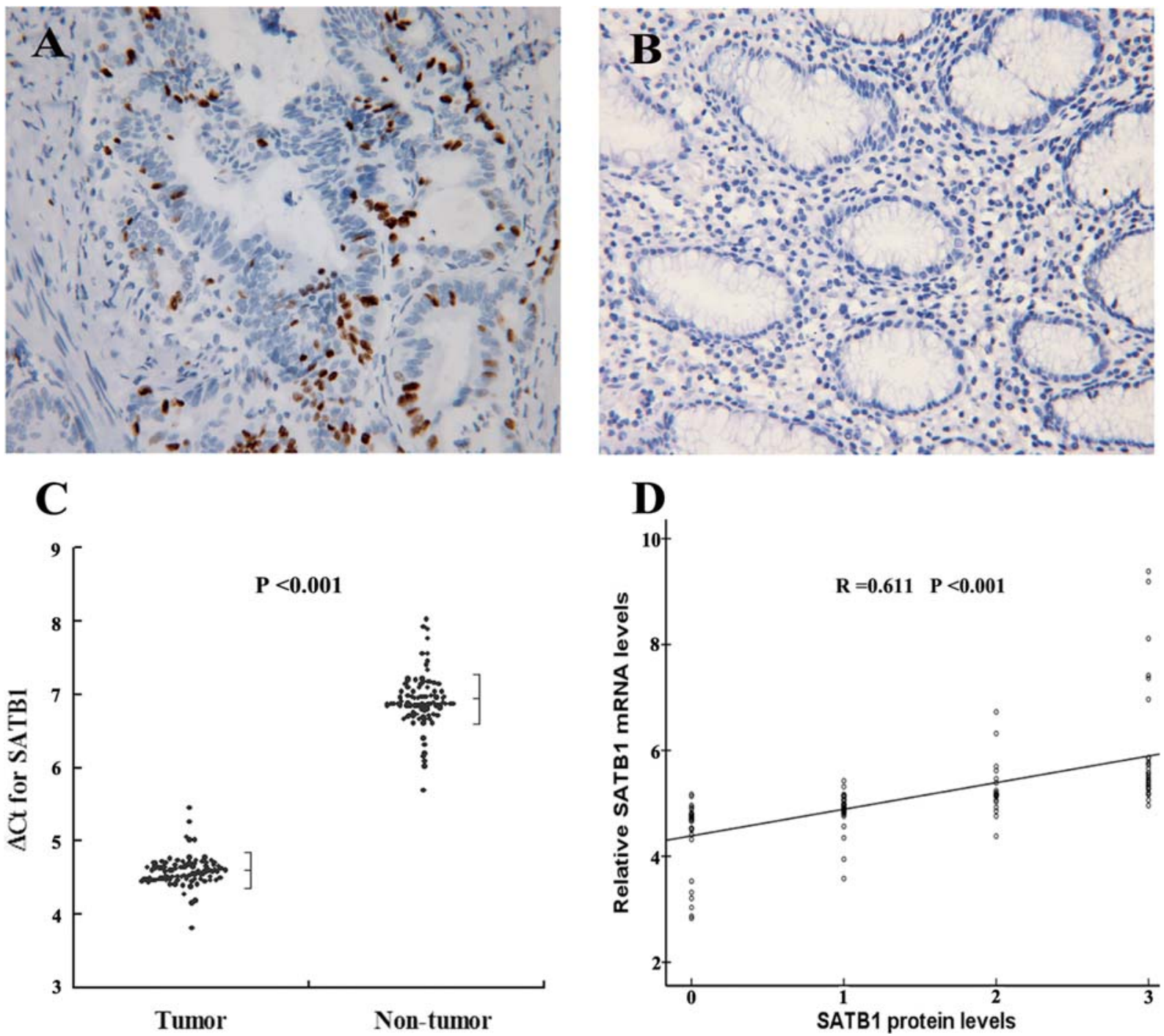

Figure 2. Expression of SATB1 is elevated in human gastric cancer tissues compared with the paired non-cancerous tissues from the same patient. Representative pictures of immunohistochemical staining for SATB1 (A and B). (A) SATB1 staining was observed in the nuclei of gastric cancer cells (x400). (B) SATB1 staining is negative in normal gastric mucosa (x400). The expression of SATB1 protein was significantly increased in cancer cells. (C) SATB1 expression in gastric cancer tissue and non-tumor tissue by quantitative real-time RT-PCR assay. The levels of SATB1 mRNA expression in tumor tissues were significantly higher than those in corresponding non-tumor tissues. The amount of SATB1 mRNA, standardized against the amount of GAPDH mRNA, was expressed as $\Delta \mathrm{Ct}=\mathrm{Ct}_{\mathrm{SATB} 1}-\mathrm{Ct}_{\mathrm{GAPDH}}$. Student's $\mathrm{t}$-test indicated a significant difference $(\mathrm{P}<0.001)$. (D) The correlation between SATB1 mRNA and protein expression in gastric cancer tissues by Pearson's coefficient correlation analysis. The SATB1 transcripts were positively correlated with SATB1 protein levels detected by immunohistochemistry $(\mathrm{R}=0.611 ; \mathrm{P}<0.001)$.

Overexpression of SATB1 in human gastric cancer. Immunohistochemical staining analysis showed that SATB1 was localized in the nuclei of the gastric cancer cells (Fig. 2A), with no immunoreactivity in the control mucosa cells (Fig. 2B). The expression of SATB1 protein was significantly increased in gastric cancer cells as compared with the normal gastric epithelial cells. Additionally, we also observed that the expression of SATB1 mRNA in cancer samples was frequently up-regulated as compared with that in the samples of adjacent normal gastric tissue $(\mathrm{P}<0.001$; Student's t-test) (Fig. 2C). The expression of SATB1 mRNA agreed well with the immunohistochemical findings ( $\mathrm{R}=0.611 ; \mathrm{P}<0.001)$ (Fig. 2D).

Relationships between SATB1 mRNA expression and clinicopathological factors. The relationships between SATB1
mRNA expression and clinicopathological characteristics were summarized in Table I. No significant difference was detected in distribution according to gender, tumor size and tumor location between the two SATB1-expression groups. However, high expression of SATB1 was significantly correlated with age $\left(\mathrm{P}=0.011 ; \chi^{2}\right.$ test $)$, depth of invasion in the gastric wall $(\mathrm{T} 1+\mathrm{T} 2$ vs. $\mathrm{T} 3+\mathrm{T} 4, \mathrm{P}=0.021)$, TNM stage (stages I + II vs. stages III + IV, $\mathrm{P}=0.037$ ), presence of lymph node metastasis $(\mathrm{P}=0.013)$ and presence of distant metastasis $(\mathrm{P}=0.018)$.

Difference in survival according to SATB1 expression status. Univariable analysis of clinicopathological factors for overall survival of 118 patients with gastric cancer was shown in Table II. It was identified that SATB1 expression, patient age, depth of tumor invasion, tumor TNM stage, 
Table II. Univariable analysis of prognostic factors in 118 patients with gastric cancer.

\begin{tabular}{|c|c|c|c|c|}
\hline Parameters & $\begin{array}{c}\text { No. of } \\
\text { patients }\end{array}$ & $\begin{array}{c}\text { No. of } \\
\text { survivors }\end{array}$ & $\begin{array}{c}\text { The overall } \\
5 \text {-year } \\
\text { survival } \\
\text { rate }(\%)\end{array}$ & P-value \\
\hline SATB1 & & & & 0.001 \\
\hline High & 56 & 8 & 14.3 & \\
\hline Low & 62 & 26 & 41.9 & \\
\hline Age (years) & & & & 0.048 \\
\hline$\geq 65$ & 55 & 11 & 20.0 & \\
\hline$<65$ & 63 & 23 & 36.5 & \\
\hline Gender & & & & 0.821 \\
\hline Male & 78 & 23 & 29.5 & \\
\hline Female & 40 & 11 & 27.5 & \\
\hline Tumor size $(\mathrm{cm})$ & & & & 0.822 \\
\hline$\geq 5$ & 71 & 21 & 29.6 & \\
\hline$<5$ & 47 & 13 & 27.7 & \\
\hline \multicolumn{5}{|l|}{ Tumor location } \\
\hline Upper & 12 & 4 & 33.3 & $0.729^{a}$ \\
\hline Middle & 43 & 13 & 30.2 & $0.715^{\mathrm{b}}$ \\
\hline Lower & 63 & 17 & 27.0 & $0.639^{c}$ \\
\hline Depth of invasion & & & & $<0.001$ \\
\hline $\mathrm{T} 1+\mathrm{T} 2$ & 51 & 27 & 52.9 & \\
\hline $\mathrm{T} 3+\mathrm{T} 4$ & 67 & 7 & 10.4 & \\
\hline TNM stage & & & & $<0.001$ \\
\hline I + II & 54 & 30 & 55.6 & \\
\hline III + IV & 64 & 4 & 6.3 & \\
\hline $\begin{array}{l}\text { Lymph node } \\
\text { metastasis }\end{array}$ & & & & 0.014 \\
\hline Present & 66 & 13 & 19.7 & \\
\hline Absent & 52 & 21 & 40.4 & \\
\hline Distant metastasis & & & & 0.037 \\
\hline Present & 16 & 1 & 6.3 & \\
\hline Absent & 102 & 33 & 32.4 & \\
\hline
\end{tabular}

${ }^{\mathrm{a}}$ Upper vs. lower; ${ }^{\mathrm{b}}$ middle vs. lower; ${ }^{\mathrm{c}}$ upper and middle vs. lower.

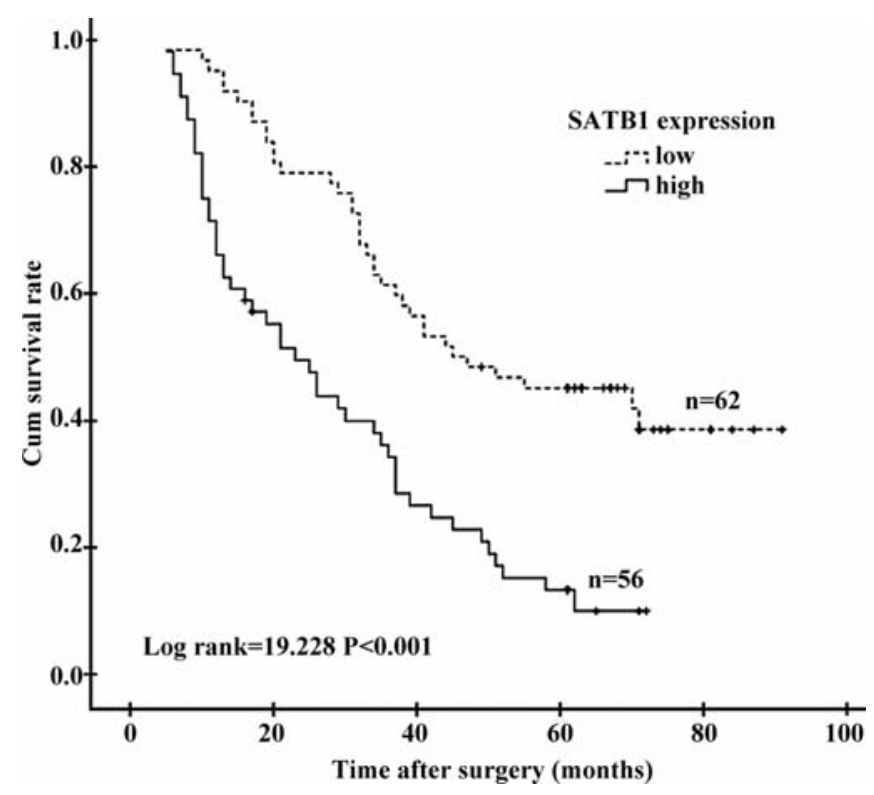

Figure 3. Kaplan-Meier analysis of overall survival rate in patients with gastric cancer grouped according to SATB1 expression status of the tumor. The 5-year overall survival rate of patients with high SATB1 expression was significantly worse than those with low SATB1 expression $(\mathrm{P}<0.001$; log-rank test).

Table III. Multivariate analysis for survival by the Cox proportional hazard regression model.

\begin{tabular}{lccr}
\hline \multirow{2}{*}{ Variables } & \multicolumn{3}{c}{ Multivariate analysis } \\
\cline { 2 - 4 } & Relative risk & $95 \%$ CI & P-value \\
\hline SATB1 expression $^{\mathrm{a}}$ & 1.709 & $1.075-2.718$ & 0.023 \\
Age $^{\mathrm{b}}$ & 1.573 & $0.987-2.506$ & 0.057 \\
Depth of invasion $^{\mathrm{c}}$ & 2.730 & $1.501-4.964$ & 0.001 \\
TNM stage $^{\mathrm{d}}$ & 4.395 & $2.538-7.613$ & $<0.001$ \\
Lymph node metastasis $^{\mathrm{e}}$ & 1.937 & $1.166-3.219$ & 0.011 \\
Distant metastasis $^{\mathrm{e}}$ & 2.248 & $1.209-4.179$ & 0.010 \\
\hline
\end{tabular}

CI, confidence interval; ahigh vs. low; ${ }^{b} \geq 65$ vs. $<65$; ${ }^{\mathrm{c}} \mathrm{T} 1+\mathrm{T} 2$

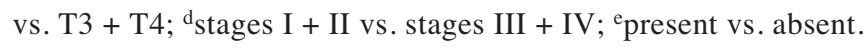

\section{Discussion}

In the present study, we reported for the first time that SATB1 expression was significantly up-regulated in gastric cancer at both mRNA and protein levels. High SATB1 expression was positively associated with age, depth of invasion, TNM stages, lymph node metastasis, and distant metastasis. An interesting finding was that the 5-year overall survival rate of patients with high SATB1 expression was significantly decreased as compared with low SATB1 expression. Furthermore, multivariate analysis indicated that SATB1 served as an independent factor for predicting poor prognosis of patients with gastric cancer. 
Invasion and metastasis are the most influential factors for clinical outcome of gastric cancer $(20,21)$. Abnormal SATB1 expression may contribute to tumor development and progression (13-16). Zhou et al reported that SATB1 mRNA expression might be associated with the development and lymph node metastasis of non-small cell lung cancer (14). Likewise, a recent study also confirmed that elevated expression of SATB1 in laryngeal squamous cell carcinoma was significantly associated with both tumor invasion and metastasis (15). In experimental models, aberrant SATB1 expression in non-aggressive cells induced the malignant phenotype in vitro and metastatic competence in vivo. On the contrary, knockdown of SATB1 in aggressive cancer cells effectively reversed tumorigenesis in vitro and tumor growth and metastasis in vivo (16). Combined with our research, we considered that SATB1 expression could play a key role in promoting tumor invasion and metastasis of gastric cancer.

It has been widely accepted that the aggressive nature of human metastatic gastric cancer is related to abnormal expression of various oncogenes and tumor suppressor genes $(22,23)$. As a genome organizer, SATB1 recruits chromatin remodeling factors and regulates the spatiotemporal expression of numerous genes involving T-cell development, tumor growth and metastasis $(15,24,25)$. Recent studies revealed that SATB1 directly up-regulated proto-oncogene $c$-myc which played a key role in tumor development and progression of gastric cancer $(13,26)$. However, $c$-myc was not induced in response to mitogen stimulation in SATB1null mice which failed to thrive and exhibited multiple defects in T-cell development (27). Li et al demonstrated that SATB1 could up-regulate the expression of secreted protein acidic and rich in cysteine (SPARC) which played an important role in inhibiting adhesion and strongly associated with tumor invasion and metastasis of gastric cancer $(28,29)$. Conversely, SATB1 could down-regulate the metastasissuppressor genes expression, such as CD82, KISS1 and NME1, which played important roles in preventing cancer cells from becoming metastatic in gastric cancer $(15,30,31)$. These observations reinforced our speculation that a large group of SATB1-targeted genes collectively induced tumor invasion and metastasis in gastric cancer. However, the mechanisms of whether and, if so, how SATB1 binds to the SATB1-targeted genes and whether SATB1 expression in gastric cancer is related to the infection status of $H$. Pylori are still needed to be clarified in further studies.

Poor prognosis of gastric cancer patients results from local invasion, tumor expansion, and distant metastasis $(32,33)$. By analyzing the prognostic significance of SATB1 expression in gastric cancer, we demonstrated that patients with high SATB1 expression had the worse clinical outcome between the two groups, which was consistent with previous reports that SATB1 expression was positively correlated with poor prognostic parameters in various malignancies (13-15). Therefore, we inferred that increased expression of SATB1 might probably contribute to shorter survival via involvement with biological aggressiveness, such as deeper tumor invasion, more frequent lymph node and distant metastasis. Another intriguing aspect of our study was a positive correlation between high SATB1 expression and age of patient which was also a significant prognostic marker for gastric cancer by univariate analysis. However, multivariate analysis demonstrated that age was not an independent prognostic predictor. We presumed that it was likely due to the applications of different analysis methods and the limitations of our small sample size.

In this study, we provided clinicopathological evidence to support SATB1 as a potential target for cancer therapy. A recent report showed that up-regulation of SATB1 played a key role in the multiphase evolution from a benign tissue to an invasive malignant tumor by not only accelerating the course of metastasis but also effectively evading the cytotoxic attack of the drugs (34). Previous studies also elucidated that CD44, a SATB1-activated gene, was widely applied as a cytotoxic and immunological therapeutic target for anticancer therapy $(16,35)$. All of these findings suggested that SATB1 had a potential value of being a novel molecular target of an anticancer drug or cancer-specific immunotherapy for the treatment of gastric cancer. However, the underlying mechanism of SATB1 as a therapeutic target still requires further investigation.

In conclusion, our findings indicated for the first time that SATB1 was aberrantly overexpressed in gastric cancer, and SATB1 expression in gastric cancer was associated with clinicopathological factors and prognosis. The high SATB1 expression, directly contributing to tumor development and progression, was shown as a novel independent prognostic marker for predicting the outcome of gastric cancer.

\section{Acknowledgements}

This study was supported by National High Technology Research and Development Program 863 Project from the Ministry of Science and Technology of China (No. 2007AA022001), National Natural Science Foundation of China (No. 30901418) and Natural Science Foundation of Hubei (No. 2009CDB056), China.

\section{References}

1. Terry MB, Gaudet MM and Gammon MD: The epidemiology of gastric cancer. Semin Radiat Oncol 12: 111-127, 2002.

2. Sakamoto J, Morita S, Kodera Y, Rahman M and Nakao A: Adjuvant chemotherapy for gastric cancer in Japan: global and Japanese perspectives. Cancer Chemother Pharmacol 54: 25-31, 2004.

3. Fuchs CS and Mayer RJ: Gastric carcinoma. N Engl J Med 333: 32-41, 1995.

4. Alberts SR, Cervantes A and van de Velde CJ: Gastric cancer: epidemiology, pathology and treatment. Ann Oncol 14 (Suppl. 2): 31-36, 2003.

5. Parkin DM, Bray F, Ferlay J and Pisani P: Global cancer statistics, 2002. CA Cancer J Clin 55: 74-108, 2005.

6. Brenner H, Rothenbacher D and Arndt V: Epidemiology of stomach cancer. Methods Mol Biol 472: 467-477, 2009.

7. Li K and Lu J: Research advances of SATB 1 on gene expression and regulation. Chin Bull Life Sci 17: 315-317, 2005.

8. Yamaguchi $\mathrm{H}$, Tateno $\mathrm{M}$ and Yamasaki K: Solution structure and DNA-binding mode of the matrix attachment regionbinding domain of the transcription factor SATB1 that regulates the T-cell maturation. J Biol Chem 281: 5319-5327, 2006

9. Kumar PP, Bischof O, Purbey PK, Notani D, Urlaub H, Dejean A and Galande S: Functional interaction between PML and SATB1 regulates chromatin-loop architecture and transcription of the MHC class I locus. Nat Cell Biol 9: 45-56, 2007. 
10. Cai S, Han HJ and Kohwi-Shigematsu T: Tissue-specific nuclear architecture and gene expression regulated by SATB1. Nat Genet 34: 42-51, 2003.

11. Cai S, Lee CC and Kohwi-Shigematsu T: SATB1 packages densely looped, transcriptionally active chromatin for coordinated expression of cytokine genes. Nat Genet 38: 1278$1288,2006$.

12. Dickinson LA, Joh T, Kohwi Y and Kohwi-Shigematsu T: A tissue-specific MAR/SAR DNA-binding protein with unusual binding site recognition. Cell 70: 631-645, 1992.

13. Patani N, Jiang W, Mansel R, Newbold R and Mokbel K: The mRNA expression of SATB1 and SATB2 in human breast cancer. Cancer Cell Int 9: 18-27, 2009.

14. Zhou LY, Liu F, Tong J, Chen QQ and Zhang FW: Expression of special AT-rich sequence-binding protein mRNA and its clinicopathological significance in non-small cell lung cancer. Nan Fang Yi Ke Da Xue Xue Bao 29: 534-537, 2009.

15. Zhao XD, Ji WY, Zhang W, He LX, Yang J, Liang HJ and Wang LL: Overexpression of SATB1 in laryngeal squamous cell carcinoma. ORL J Otorhinolaryngol Relat Spec 72: 1-5, 2010.

16. Han HJ, Russo J, Kohwi Y and Kohwi-Shigematsu T: SATB1 reprogrammes gene expression to promote breast tumour growth and metastasis. Nature 452: 187-193, 2008.

17. Omejc M, Juvan R, Jelenc F and Repse S: Lymph node metastases in gastric cancer: correlation between new and old UICC TNM classification. Int Surg 86: 14-19, 2001.

18. Ogawa $\mathrm{K}$, Utsunomiya $\mathrm{T}$, Mimori $\mathrm{K}$, et al: Clinical significance of human kallikrein gene 6 messenger RNA expression in colorectal cancer. Clin Cancer Res 11: 2889-2893, 2005.

19. Bièche I, Onody P, Laurendeau I, Olivi M, Vidaud D, Lidereau R and Vidaud M: Real-time reverse transcription-PCR assay for future management of ERBB2-based clinical applications. Clin Chem 45: 1148-1156, 1999.

20. Siewert JR, Böttcher K, Stein HJ and Roder JD: Relevant prognostic factors in gastric cancer: ten-year results of the German Gastric Cancer Study. Ann Surg 228: 449-461, 1998.

21. Adachi Y, Yasuda K, Inomata M, Sato K, Shiraishi N and Kitano S: Pathology and prognosis of gastric carcinoma: well versus poorly differentiated type. Cancer 89: 1418-1424, 2000.

22. Tahara E: Molecular aspects of invasion and metastasis of stomach cancer. Verh Dtsch Ges Pathol 84: 43-49, 2000.

23. Xie K and Huang S: Regulation of cancer metastasis by stress pathways. Clin Exp Metastasis 20: 31-43, 2003.
24. Galande S, Purbey PK, Notani D and Kumar PP: The third dimension of gene regulation: organization of dynamic chromatin loopscape by SATB1. Curr Opin Genet Dev 17: 408414, 2007.

25. Yasui D, Miyano M, Cai S, Varga-Weisz P and KohwiShigematsu T: SATB1 targets chromatin remodelling to regulate genes over long distances. Nature 419: 641-645, 2002.

26. Burbano RR, Assumpção PP, Leal MF, et al: C-MYC locus amplification as metastasis predictor in intestinal-type gastric adenocarcinomas: CGH study in Brazil. Anticancer Res 26: 2909-2914, 2006.

27. Alvarez JD, Yasui DH, Niida H, Joh T, Loh DY and KohwiShigematsu T: The MAR-binding protein SATB1 orchestrates temporal and spatial expression of multiple genes during T-cell development. Genes Dev 14: 521-535, 2000.

28. Wang CS, Lin KH, Chen SL, Chan YF and Hsueh S: Overexpression of SPARC gene in human gastric carcinoma and its clinic-pathologic significance. Br J Cancer 91: 1924-1930, 2004.

29. Li K, Cai R, Dai BB, et al: SATB1 regulates SPARC expression in K562 cell line through binding to a specific sequence in the third intron. Biochem Biophys Res Commun 356: 6-12, 2007.

30. Steeg PS: Metastasis suppressors alter the signal transduction of cancer cells. Nat Rev Cancer 3: 55-63, 2003.

31. Yu GZ, Chen Y, Ni CR, Wang GD, Qian JX and Wang JJ: Reduced protein expression of metastasis-related genes ( $\mathrm{nm} 23$, KISS1, KAI1 and p53) in lymph node and liver metastases of gastric cancer. Int J Exp Pathol 88: 175-183, 2007.

32. Kolev Y, Uetake H, Iida S, Ishikawa T, Kawano $T$ and Sugihara K: Prognostic significance of VEGF expression in correlation with COX-2, microvessel density, and clinicopathological characteristics in human gastric carcinoma. Ann Surg Oncol 14: 2738-2747, 2007.

33. Kouraklis G, Katsoulis IE, Theocharis S, et al: Does the expression of cyclin $\mathrm{E}, \mathrm{pRb}$, and p21 correlate with prognosis in gastric adenocarcinoma? Dig Dis Sci 54: 1015-1020, 2009.

34. Li QQ, Chen ZQ, Xu JD, Cao XX, Chen Q, Liu XP and Xu ZD: Overexpression and involvement of special AT-rich sequence binding protein 1 in multidrug resistance in human breast carcinoma cells. Cancer Sci 101: 80-86, 2010.

35. Weber GF: The metastasis gene osteopontin: a candidate target for cancer therapy. Biochim Biophys Acta 1552: 61-85, 2001. 